\title{
Degradation of Exopolysaccharides from Lactic Acid Bacteria by Thermal, Chemical, Enzymatic and Ultrasound Stresses
}

\author{
Carsten Nachtigall *D, Harald Rohm and Doris Jaros \\ Chair of Food Engineering, Institute of Natural Materials Technology, Technische Universität Dresden, \\ 01062 Dresden, Germany; harald.rohm@tu-dresden.de (H.R.); doris.jaros@tu-dresden.de (D.J.) \\ * Correspondence: carsten.nachtigall@tu-dresden.de; Tel.: +49-351-463-38797
}

Citation: Nachtigall, C.; Rohm, H.; Jaros, D. Degradation of

Exopolysaccharides from Lactic Acid Bacteria by Thermal, Chemical, Enzymatic and Ultrasound Stresses. Foods 2021, 10, 396. https://doi.org/ $10.3390 /$ foods 10020396

Academic Editor: Lovedeep Kaur

Received: 19 January 2021

Accepted: 8 February 2021

Published: 11 February 2021

Publisher's Note: MDPI stays neutral with regard to jurisdictional claims in published maps and institutional affiliations.

Copyright: (c) 2021 by the authors. Licensee MDPI, Basel, Switzerland. This article is an open access article distributed under the terms and conditions of the Creative Commons Attribution (CC BY) license (https:// creativecommons.org/licenses/by/ $4.0 /)$.

\begin{abstract}
During isolation, exopolysaccharides (EPS) from lactic acid bacteria are subject of thermal, chemical, enzymatic or ultrasound stress of different intensity that may affect macromolecular properties, for instance molecular mass or (intrinsic) viscosity. These parameters are, however, crucial, as they are associated with the technofunctional potential of EPS replacing commercial thickeners in nonfermented products. The aim of this study was to systematically examine treatments EPS are usually exposed to during isolation and to investigate the underlying degradation mechanisms. Solutions $(1.0 \mathrm{~g} / \mathrm{L})$ of EPS from Streptococcus thermophilus, isolated as gently as possible, and commercial dextran were analyzed for molecular mass distributions as representative measure of molecule alterations. Generally, acid, excessive heat and ultrasonication, intensified by simultaneous application, showed EPS degradation effects. Thus, recommendations are given for isolation protocols. Ultrasonic degradation at $114 \mathrm{~W} / \mathrm{cm}^{2}$ fitted into the random chain scission model and followed third- (S. thermophilus EPS) or second-order kinetics (dextran). The degradation rate constant reflects the sensitivity to external stresses and was DGCC7710 EPS > DGCC7919 EPS > dextran > ST143 EPS. Due to their exceptional structural heterogeneity, the differences could not be linked to individual features. The resulting molecular mass showed good correlation $\left(r^{2}=0.99\right)$ with dynamic viscosity.
\end{abstract}

Keywords: degradation; dextran; exopolysaccharides; lactic acid bacteria; molecular mass; random scission model; shearing; Streptococcus thermophilus; ultrasound

\section{Introduction}

For the production of fermented dairy products, for instance, yoghurt or (fresh) cheese, lactic acid bacteria such as Streptococcus thermophilus, Lactococcus lactis or Lactobacillus delbrueckii ssp. bulgaricus are widely used as starter cultures. Associated to their growth, some strains of these species are able to produce exopolysaccharides (EPS) in situ and are thus beneficial for the texture and sensory properties of the fermented product, as EPS enhance the water binding capacity, reduce syneresis, increase the viscosity of milk gels or enhance their stability against shearing [1-4]. This can lead to savings of commercial hydrocolloids in fermented products or even clean label products.

Amongst lactic acid bacteria, large variations in EPS structure are evident. Genera such as Streptococcus or Lactococcus produce hetero EPS that largely vary concerning monosaccharide composition, anomeric conformation of the monosaccharides, glycosidic linkages, side chains and molecular mass [5,6]. Homo EPS produced by Weissella or Leuconostoc, for instance, dextran, mainly differ in their degree of branching, linkage type of the backbone and their molecular mass [3,7]. Furthermore, EPS can be distinguished concerning their location: while free EPS (fEPS) are released into the fermentation medium, capsular or cell-bound EPS (cEPS) cover the cell surface through covalent linkages. However, up to now, little is known on relationships between specific structural elements, macromolecular properties of EPS and EPS functionality in fermented products [8]. Pronounced viscosityenhancing properties were attributed to the presence of side chains and reduced flexibility 
of the molecules caused by, e.g., long backbones, $\beta$ instead of $\alpha$ bonds, and 1,4-linkages instead of 1,2 or 1,3 [9,10]. The resulting intermolecular hydrogen bonds are responsible for hydrophilic interactions between EPS molecules and, therefore, effects on shear and intrinsic viscosity [5].

For a comprehensive macromolecular and structural analysis of EPS and a deeper insight into their functionality, EPS need to be resilient against conformational and/or structural changes by the underlying isolation procedure. Single isolation steps (Table 1) might affect the final isolate and need to be selected by, e.g., the required purity [11]. Heating is used for the detachment of cEPS [12] and may increase EPS yield [11,13], but could also reduce molecular mass and intrinsic viscosity. This leads to altered antioxidant properties as was shown for polysaccharides from Inonotus obliquus [14]. Protein removal is usually carried out by precipitation with strong acids, but trichloroacetic acid (TCA) may reduce the molecular mass of EPS as a consequence of acid hydrolysis [13]. Furthermore, co-precipitation can reduce EPS yield [11]. Other than acids, some authors subjected EPS containing media to alkaline conditions to release cEPS or for purification purposes $[15,16]$.

Table 1. Processing steps commonly used for exopolysaccharides (EPS) isolation and purification ${ }^{1}$.

\begin{tabular}{|c|c|}
\hline Processing Step & Common Methods \\
\hline Detachment of cEPS & Heating $^{2}$, ultrasound $^{2}, \mathrm{NaOH}$ treatment $^{2}$ \\
\hline Cell separation & Microfiltration, centrifugation \\
\hline Protein removal & TCA $^{3}$ precipitation $^{2}$, enzymatic hydrolysis ${ }^{2}$ \\
\hline Concentration & Microfiltration, ultrafiltration \\
\hline Purification & $\begin{array}{l}\text { Diafiltration, dialysis, precipitation, } \mathrm{NaOH} \text { treatment } \\
2 \text {, preparative size exclusion chromatography }\end{array}$ \\
\hline Drying & Freeze drying, spray drying \\
\hline Resolvatization & Heating ${ }^{2}$, ultrasound assistance ${ }^{2}$ \\
\hline
\end{tabular}

${ }^{1}$ taken from [1,13,17-20]; ${ }^{2}$ effects on EPS investigated in this study; ${ }^{3}$ TCA: trichloroacetic acid.

Ultrasonication, considered a green technology due to its simple, safe and environmentfriendly application [21,22], can be used for releasing cEPS and, after drying, for resolvatization and targeted physical modification. Several studies point on increased solubility [23,24] and improved functionality or bioactivity [22,25] of bacterial or plant-based polysaccharides after ultrasonication. These effects were explained by reduced molecular mass and narrow molecular mass distribution accompanied by reduced viscosity [26-30]. However, FT-IR or NMR experiments revealed a mostly unchanged primary structure after shearing $[21,31]$. The amount of degradation is determined by ultrasound parameters (frequency, amplitude) and solvation parameters (e.g., structure of the polymer, concentration, solvent, temperature) [32].

Polymer degradation mostly follows first- or second-order kinetics [22,31,33]. For a correct estimation of ultrasound-induced EPS degradation, it is necessary to know about the chain scission mechanism. Two models have mainly been used to describe chain scission of polymers: (I) The random chain scission model originally proposed by Schmid et al. [34] is based on a random breakdown of covalent bonds in the polymer chain $(\mathrm{P}(\mathrm{x}) \rightarrow \mathrm{P}(\mathrm{x}-\mathrm{y})+$ $\mathrm{P}(\mathrm{y}))$. The rate of degradation decreases with decreasing molecular mass of the polymer. The model can be described as shown in Equation (1):

$$
\frac{\mathrm{M}_{\mathrm{N}, \infty}}{\mathrm{M}_{\mathrm{N}, \mathrm{t}}}+\ln \left(1-\frac{\mathrm{M}_{\mathrm{N}, \infty}}{\mathrm{M}_{\mathrm{N}, \mathrm{t}}}\right)=-\frac{\mathrm{k}_{1}}{\mathrm{c}} \mathrm{t} \cdot\left(\frac{\mathrm{M}_{\mathrm{N}, \infty}}{\mathrm{m}}\right)^{2}+\frac{\mathrm{M}_{\mathrm{N}, \infty}}{\mathrm{M}_{\mathrm{N}, 0}}+\ln \left(1-\frac{\mathrm{M}_{\mathrm{N}, \infty}}{\mathrm{M}_{\mathrm{N}, 0}}\right)
$$

(II) The midpoint chain scission model follows the assumption of a continuous degradation, and chain scission occurs always at the midpoint of the polymer $(\mathrm{P}(\mathrm{x}) \rightarrow 2 \cdot \mathrm{P}(\mathrm{x} / 2))$. It can be described with the following equation $[35,36]$ :

$$
\ln \left(\frac{\mathrm{M}_{\mathrm{N}, 0}-\mathrm{M}_{\mathrm{N}, \infty}}{\mathrm{M}_{\mathrm{N}, \mathrm{t}}-\mathrm{M}_{\mathrm{N}, \infty}}\right)=\mathrm{k}_{2} \cdot \mathrm{M}_{\mathrm{N}, \infty} \cdot \mathrm{t}
$$


$\mathrm{M}_{\mathrm{N}, 0}, \mathrm{M}_{\mathrm{N}, \mathrm{t}}$ and $\mathrm{M}_{\mathrm{N}, \infty}$ represent the number average molecular mass before ultrasonication, after a certain ultrasonication time $t$ and at $t=\infty$, respectively; $\mathrm{k}_{1}$ and $\mathrm{k}_{2}$ are degradation constants of the random chain scission model and the midpoint scission model, respectively; $\mathrm{m}$ is the molecular mass of a monomer and $\mathrm{c}$ is the concentration of the polymer in solution.

In summary, exposition of EPS to thermal, physical, chemical or enzymatic stress usually applied during isolation or post-isolation processing may lead to intended or undesired changes in EPS molecules, mainly in their molecular mass. This affects further macromolecular properties such as (intrinsic) viscosity and thus EPS functionality when applied in nonfermented products. Therefore, this study aims to examine the impact of different stress factors on the molecular mass of EPS as a quick-to-determine parameter of molecule alteration. To avoid any effects of fermentation medium compounds, aqueous EPS solutions were used for this purpose. Based on the results, recommendations are given for isolation protocols to obtain EPS in their native state. Ultrasonication was also applied to examine degradation kinetics and shear resistance of EPS to link these data to structural features of the EPS.

\section{Materials and Methods}

\subsection{Materials}

Dextran from Leuconostoc ssp. and pronase E, a protease from Streptomyces griseus, were purchased from Sigma-Aldrich Chemie GmbH (Steinheim, Germany). Cryocultures of Streptococcus thermophilus DGCC7710, DGCC7919 (Danisco Deutschland GmbH, Niebüll, Germany) and ST143 (Christian Hansen A/S, Hørsholm, Denmark) were stored at $-80{ }^{\circ} \mathrm{C}$ until use.

\subsection{Exopolysaccharide Production and Reference Isolation Procedure}

EPS of all S. thermophilus strains were produced in bioreactor cultivations $[37,38]$. Briefly, $60 \mathrm{~g} / \mathrm{L}$ (DGCC7710) or $100 \mathrm{~g} / \mathrm{L}$ (DGCC7919; ST143) whey permeate solution (Wheyco $\mathrm{GmbH}$, Altentreptow, Germany) was enriched with $10 \mathrm{~g} / \mathrm{L}$ tryptone, $2 \mathrm{~g} / \mathrm{L}$ ammonium sulphate, $9 \mathrm{~g} / \mathrm{L}$ glucose and $34.2 \mathrm{~g} / \mathrm{L}$ lactose and fermented in $5 \mathrm{~L}$ reactors (Applikon Biotechnology BV, Delft, The Netherlands) at $40{ }^{\circ} \mathrm{C}$ under anaerobic conditions for approx. $24 \mathrm{~h}$. pH was kept constant at 6.0 by automatic titration of $10 \mathrm{~mol} / \mathrm{L} \mathrm{NaOH}$. Cultivations were stopped at the end of the exponential growth phase, and the media were stored at $-80^{\circ} \mathrm{C}$ until EPS isolation.

For the reference EPS isolation procedure, all steps considered to affect molecular mass were omitted to allow a systematic investigation later in this study (see Table 1). After diluting the cultivation broth 1:2 with $9 \mathrm{~g} / \mathrm{L}$ sodium chloride $+0.2 \mathrm{~g} / \mathrm{L}$ sodium azide, cells were separated by crossflow filtration through $0.1 \mu \mathrm{m}$ membranes at $40{ }^{\circ} \mathrm{C}$ (Sartorius Stedim Biotech $\mathrm{GmbH}$, Göttingen, Germany). For subsequent concentration and purification, $5 \mathrm{kDa}$ membranes were used and EPS precipitation in the remaining diafiltration retentate was conducted by adding two volume units of cold acetone. After storage at $6{ }^{\circ} \mathrm{C}$ for $24 \mathrm{~h}$, centrifugation $\left(4^{\circ} \mathrm{C}, 15 \mathrm{~min}, 19,000 \mathrm{~g}\right)$, and resuspension in demineralized water, the EPS were freeze-dried (Alpha 1-2, Martin Christ Gefriertrocknungsanlagen, Osterode am Harz, Germany) and subsequently stored in a desiccator until further use.

\subsection{Stresses applied to Exopolysaccharide Solutions}

EPS solutions $(1.0 \mathrm{~g} / \mathrm{L})$ were prepared by dissolving freeze-dried EPS in deionized water and gentle stirring for $24 \mathrm{~h}$ at room temperature. The EPS solutions were then subjected to different treatments: (a) $1 \mathrm{~mL}$ was incubated at 60,80 or $90^{\circ} \mathrm{C}$ for 10,30 or 60 min each and subsequently cooled to room temperature in an ice bath; (b) $140 \mu \mathrm{L}$ of TCA $(800 \mathrm{~g} / \mathrm{L})$ was added to $1 \mathrm{~mL}$ EPS solution (resulting TCA concentration: $98 \mathrm{~g} / \mathrm{L})$, stirred for $30 \mathrm{~s}$, incubated for $4 \mathrm{~h}$ at room temperature, neutralized with $1 \mathrm{~mol} / \mathrm{L} \mathrm{NaOH}$ (optional) and dialyzed against deionized water for $48 \mathrm{~h}$ (molecular mass cut-off: 6-8 kDa); (c) $1 \mathrm{~mL}$ of $2 \mathrm{~mol} / \mathrm{L} \mathrm{NaOH}$ was added to $1 \mathrm{~mL}$ EPS solution, incubated for $4 \mathrm{~h}$ or $24 \mathrm{~h}$ at room temperature with gentle stirring, neutralized with $1 \mathrm{~mol} / \mathrm{L} \mathrm{HCl}$ and dialyzed as described 
above; (d) $50 \mu \mathrm{L}$ of a freshly prepared pronase E solution $(4.8 \mathrm{mg} / \mathrm{mL}, \mathrm{pH} 7.5)$ was added to $1 \mathrm{~mL}$ EPS solution adjusted to $\mathrm{pH}$ 7.0-8.0, incubated in a shaking water bath for $24 \mathrm{~h}$ at $37^{\circ} \mathrm{C}$ and centrifuged for $5 \mathrm{~min}$ at $14,500 \mathrm{~g}$ and room temperature. The supernatant was dialyzed for $48 \mathrm{~h}$ as described above; (e) $0.5 \mathrm{~mL}$ of a $0.2 \mathrm{~mol} / \mathrm{L} \mathrm{HCl}$ was added to $1 \mathrm{~mL}$ EPS solution for $\mathrm{pH}$ adjustment. Subsequently, $0.25 \mathrm{~mL}$ of a freshly prepared pepsin solution $(4 \mathrm{~g} / \mathrm{L})$ was added, the mixture incubated in a shaking water bath for $24 \mathrm{~h}$ at $37^{\circ} \mathrm{C}$ and centrifuged for $5 \mathrm{~min}$ at $14,500 \mathrm{~g}$ and room temperature. The supernatant was dialyzed for $48 \mathrm{~h}$ as described above; (f) $2 \mathrm{~mL}$ of EPS solution was sonicated in an ultrasonic water bath (Elma Schmidbauer $\mathrm{GmbH}$, Singen, Germany) at $37 \mathrm{kHz}$ for 30 or $60 \mathrm{~min}$ at room temperature or $80^{\circ} \mathrm{C}$; (g) $2 \mathrm{~mL}$ EPS solution was treated with an UDS751 ultrasonic disintegrator (Topas $\mathrm{GmbH}$, Dresden, Germany) at $24 \mathrm{kHz}$ for 0-30 min and amplitudes from $10-100 \%$. During treatment, the samples were cooled in an ice bath.

All experiments were carried out in duplicate or triplicate.

\subsection{Determination of Ultrasound Intensity}

The energy input of the ultrasonic disintegrator was determined calorimetrically $[39,40]$. The temperature of a defined amount of deionized water $(\mathrm{m}=100.0 \mathrm{~g})$ was adjusted to $20.0 \pm 0.1{ }^{\circ} \mathrm{C}$. Subsequently, sonication was performed in a thermally insulated vessel for 15 min with amplitudes adjusted to 10, 30, 40, 50, 70 and 100\%. The time-dependent temperature increase of the sample was recorded with a testo 175 data logger (Testo SE \& Co. KGaA, Titisee-Neustadt, Germany; accuracy: $0.1 \mathrm{~K}$ ). From the slope $\mathrm{dT} / \mathrm{dt}[\mathrm{K} / \mathrm{s}]$, the ultrasonic power input $\mathrm{P}[\mathrm{W}]$ can be calculated as

$$
\mathrm{P}=\mathrm{m} \cdot \mathrm{c}_{\mathrm{p}} \cdot \frac{\mathrm{dT}}{\mathrm{dt}}
$$

with $c_{p}=4.18 \mathrm{~kJ} /(\mathrm{kg} \cdot \mathrm{K})$ being the heat capacity of water. Ultrasound power density I $\left[\mathrm{W} / \mathrm{cm}^{2}\right]$ is defined as the power per area of the sonicator probe tip A $\left[\mathrm{cm}^{2}\right]$ :

$$
\mathrm{I}=\frac{\mathrm{P}}{\mathrm{A}}
$$

In our experiments, a probe tip with a radius of $1.6 \mathrm{~mm}$ was used, and a linear correlation $\left(\mathrm{r}^{2}=0.99\right)$ was observed between the amplitude adjusted at the ultrasonic disintegrator and the power input $(0.8 \mathrm{~W} \leq \mathrm{P} \leq 9.1 \mathrm{~W})$, resulting in an ultrasound density ranging from 10.0 to $114.2 \mathrm{~W} / \mathrm{cm}^{2}$.

\subsection{Molecular Mass and Mono-/Disaccharide Determination}

The molecular mass distribution of the exopolysaccharides, relative to pullulan standards, was determined with GPC-RI (Knauer Wissenschaftliche Geräte GmbH, Berlin, Germany) and described by the weight average molecular mass $\mathrm{M}_{M}[\mathrm{Da}]$ and the number average molecular mass $\mathrm{M}_{\mathrm{N}}$ [Da] (for details, see [38]). The polydispersity index is given by $\mathrm{Ð}=\mathrm{M}_{\mathrm{M}} / \mathrm{M}_{\mathrm{N}}[-]$.

The mono- and disaccharide content of EPS solutions was analyzed with HPLC-RI as described previously [38]. Detection limits were $117 \mathrm{mg} / \mathrm{L}$ (glucose), $41 \mathrm{mg} / \mathrm{L}$ (galactose) and $20 \mathrm{mg} / \mathrm{L}$ (rhamnose).

\subsection{Viscosity of Exopolysaccharide Solutions}

The dynamic viscosity $\eta[\mathrm{mPa} \cdot \mathrm{s}]$ of aqueous exopolysaccharide solutions (assumption: $\rho=1.0 \mathrm{~g} / \mathrm{mL}$ ) was determined with a LOVIS rolling ball viscometer (Anton Paar $\mathrm{GmbH}$, Ostfildern, Germany) [37]. The rolling time of a gold-coated steel ball ( $\mathrm{d}=1.50 \mathrm{~mm}$, $\rho=7.88 \mathrm{~g} / \mathrm{mL}$ ) in a $1.59 \mathrm{~mm}$ diameter capillary was measured at $20^{\circ} \mathrm{C}$ in six-fold replication at an angle of $70^{\circ}$. 


\subsection{Statistics}

Data are expressed as arithmetic mean \pm standard deviation $(n>2)$ or arithmetic mean \pm half deviation range $(n=2)$. Differences were statistically tested with the StudentNewman-Keuls test $(p<0.05)$ after performing one-way analysis of variance (ANOVA) using SAS ${ }^{\circledR}$ University Edition 6p.2 (SAS ${ }^{\circledR}$ Institute, Cary, NC, USA).

\section{Results and Discussion}

\subsection{Effects of Thermal Treatment on Molecular Mass}

The aim of a heat treatment during isolation is to inactivate cells, detach capsular EPS or improve EPS solubility $[17,20]$. The fEPS from the three $S$. thermophilus strains showed similar $\mathrm{M}_{\mathrm{M}}$ when untreated $\left(2.98 \times 10^{6}, 3.94 \times 10^{6}\right.$ and $2.20 \times 10^{6}$ Da for DGCC7710 fEPS, ST143 fEPS and DGCC7919 fEPS, respectively), and $\mathrm{M}_{\mathrm{M}}$ of dextran from L. mesenteroides was approx. one magnitude lower $\left(2.29 \times 10^{5} \mathrm{Da}\right)$. These $\mathrm{M}_{\mathrm{M}}$ were not significantly affected by thermal treatment at 60 or $80^{\circ} \mathrm{C}$ for up to $60 \mathrm{~min}$ (Figure 1). At $90^{\circ} \mathrm{C}, 10 \mathrm{~min}$ residence time did not affect $\mathrm{M}_{\mathrm{M}}$ of fEPS from DGCC7710 and DGCC7919 but after $30 \mathrm{~min}, \mathrm{M}_{\mathrm{M}}$ decreased significantly to $2.40 \times 10^{6}$ and $1.96 \times 10^{6} \mathrm{Da}$, respectively, and after $60 \mathrm{~min}$, to $2.10 \times 10^{6}$ and $1.57 \times 10^{6} \mathrm{Da}$, respectively. For ST143 fEPS, however, $\mathrm{M}_{\mathrm{M}}$ was larger after heating, e.g., $6.27 \times 10^{6} \mathrm{Da}$ after $30 \mathrm{~min}$ at $90^{\circ} \mathrm{C}$. We assume that these EPS were not completely dissolved after stirring for $24 \mathrm{~h}$ at room temperature, and EPS agglomerates impaired filtration prior to GPC measurements. Improved EPS solubility and disaggregation of larger agglomerates by heating allowed the molecules to pass the filter, resulting in higher $\mathrm{M}_{M}$ as well as $Ð$ (from initially 3.08 to 3.97 after $60^{\circ} \mathrm{C}$ for $60 \mathrm{~min}$, to 4.52 after $80^{\circ} \mathrm{C}$ for $10 \mathrm{~min}$, and to 4.22 after $90^{\circ} \mathrm{C}$ for $10 \mathrm{~min}$ ). This effect was overlaid by a heat-triggered molecule breakdown which was accelerated at higher temperature and longer incubation time and in accordance with findings from other authors: $A$ decreased $\mathrm{M}_{\mathrm{M}}$ and lower apparent viscosity after a heat treatment was observed for scleroglucan [41], polysaccharides from black garlic [42] and polysaccharides from Inonotus obliquus [14].

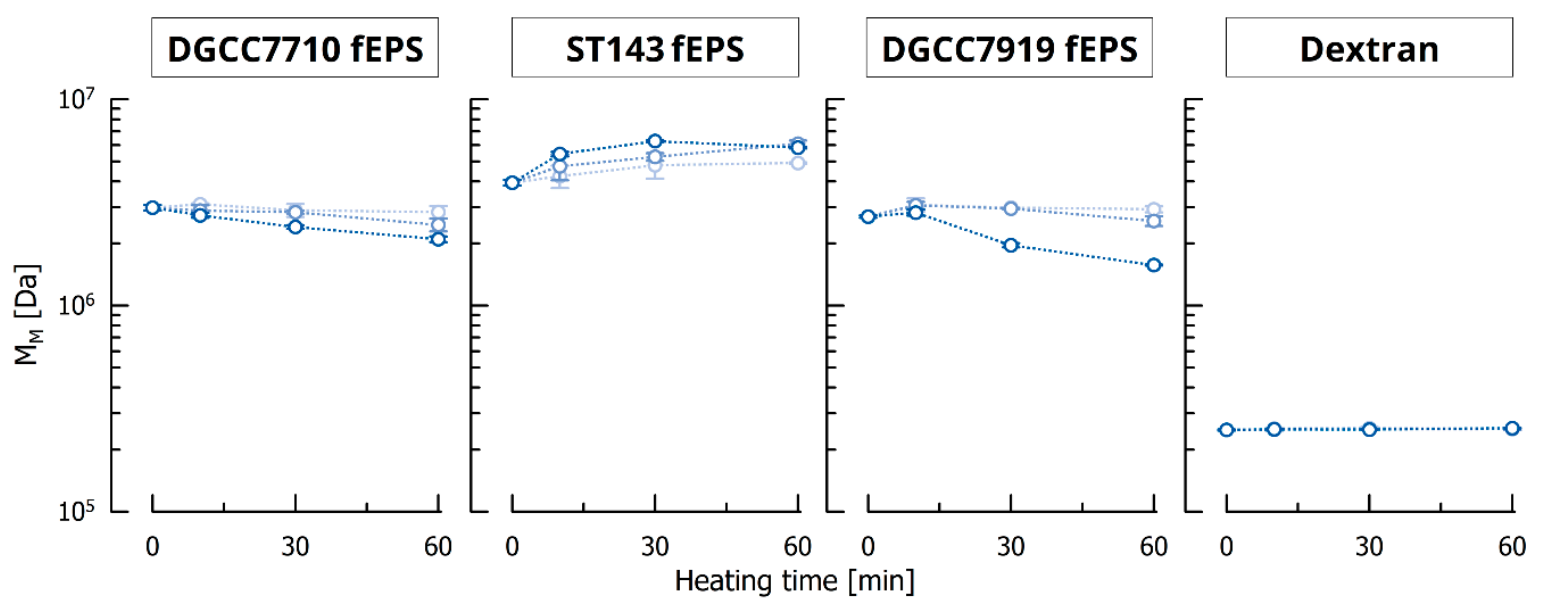

Figure 1. Weight average molecular mass $\mathrm{M}_{\mathrm{M}}$ of EPS after thermal treatment of $1.0 \mathrm{~g} / \mathrm{L}$ solutions at 60,80 and $90{ }^{\circ} \mathrm{C}($ light to dark blue).

$\mathrm{M}_{\mathrm{M}}$ of dextran was not affected by heating at all. In all sample solutions, neither mononor disaccharides were detected. This suggests that bond cleavage occurred anywhere within the EPS molecules and not at the end of the molecule chain.

\subsection{Effects of Chemical Treatment on Molecular Mass}

Solutions of DGCC7710 fEPS, ST143 fEPS and dextran were kept at $98 \mathrm{~g} / \mathrm{L}$ TCA for $4 \mathrm{~h}$, which is the time a sample is usually exposed to acidic conditions for precipitating protein and peptide residues from the fermentation medium during EPS isolation. The treatment had a significant effect on $\mathrm{M}_{\mathrm{M}}$ of DGCC7710 fEPS (decrease by approx. one magnitude), but 
not on $\mathrm{M}_{\mathrm{M}}$ of ST143 fEPS and dextran (\#I in Table 2). For DGCC7710 fEPS, this pronounced decrease in $\mathrm{M}_{\mathrm{M}}$ could be attenuated by introducing a subsequent neutralization step (\#II), resulting in a $\mathrm{M}_{\mathrm{M}}$ of $2.54 \times 10^{6} \mathrm{Da}$. As some studies used also alkaline conditions for cEPS detachment and purification purposes, this was also investigated in this study. After 4 and $24 \mathrm{~h}$ of exposure to $\mathrm{pH} \approx 14$ with $\mathrm{NaOH}, \mathrm{M}_{\mathrm{M}}$ of DGCC7710 fEPS was reduced to $2.36 \times 10^{6}$ and $1.82 \times 10^{6} \mathrm{Da}$, respectively. The reduction was less pronounced for ST143 fEPS $\left(2.61 \times 10^{6}\right.$ and $2.20 \times 10^{6} \mathrm{Da}$, respectively). Molecular mass of dextran was not affected by $\mathrm{pH} \approx 14$.

Table 2. Weight average molecular mass $\mathrm{M}_{\mathrm{M}}$ of EPS after thermal and acid stress of $1.0 \mathrm{~g} / \mathrm{L}$ solutions in different treatment order. Ref: reference; b.d.l.: below detection level. Mean values with different superscripts in a column indicate statistical differences $(\alpha=0.05)$.

\begin{tabular}{|c|c|c|c|c|c|c|}
\hline & \multicolumn{3}{|c|}{ Treatment Order } & \multicolumn{3}{|c|}{$\mathrm{M}_{\mathrm{M}}\left[\times 10^{6} \mathrm{Da}\right]$} \\
\hline & $\begin{array}{c}\text { Acid } \\
\text { Treatment }\end{array}$ & Neutralization $^{2}$ & Heating $^{3}$ & $\begin{array}{c}\text { DGCC7710 } \\
\text { fEPS }\end{array}$ & $\begin{array}{l}\text { ST143 } \\
\text { fEPS }\end{array}$ & Dextran \\
\hline Ref & - & - & - & $2.98 \pm 0.09^{a}$ & $3.94 \pm 0.12^{a}$ & $0.22 \pm 0.01^{\mathrm{a}}$ \\
\hline I & 1 & - & - & $0.36 \pm 0.02^{c}$ & $3.53 \pm 0.13^{a}$ & $0.23 \pm 0.01^{a, b}$ \\
\hline II & 1 & 2 & - & $2.54 \pm 0.15^{b}$ & $3.62 \pm 0.02^{\mathrm{a}}$ & $0.21 \pm 0.01^{\mathrm{a}, \mathrm{b}}$ \\
\hline III & 1 & - & 2 & b.d.l. & b.d.1. & $0.04 \pm 0.01^{\mathrm{c}}$ \\
\hline IV & 1 & 3 & 2 & b.d.l. & b.d.l. & $0.04 \pm 0.01^{\mathrm{c}}$ \\
\hline $\mathrm{V}$ & 1 & 2 & 3 & $2.49 \pm 0.06^{b}$ & $3.70 \pm 0.37^{\mathrm{a}}$ & $0.22 \pm 0.01^{\mathrm{a}, \mathrm{b}}$ \\
\hline VI & 2 & - & 1 & $0.45 \pm 0.01^{\mathrm{c}}$ & $3.79 \pm 0.18^{a}$ & $0.22 \pm 0.01^{b}$ \\
\hline VII & 2 & 3 & 1 & $2.22 \pm 0.01^{b}$ & $3.41 \pm 0.15^{\mathrm{a}}$ & $0.23 \pm 0.01^{\mathrm{a}, \mathrm{b}}$ \\
\hline
\end{tabular}

${ }^{1} 98 \mathrm{~g} / \mathrm{L}$ trichloroacetic acid (TCA), incubation time: $4 \mathrm{~h} ;{ }^{2} 1 \mathrm{~mol} / \mathrm{L} \mathrm{NaOH} ;{ }^{3} 90^{\circ} \mathrm{C}, 10 \mathrm{~min}$ and subsequent cooling to room temperature in an ice bath.

For EPS isolation, it is also common practice to combine different steps (e.g., heat and acid treatment). In all subsequent experiments, we combined heating for $10 \mathrm{~min}$ at $90^{\circ} \mathrm{C}$, the most intense conditions where $\mathrm{M}_{\mathrm{M}}$ was not affected, and subsequent cooling to room temperature in an ice bath with a TCA treatment. When the TCA treatment was applied first, this resulted, however, in a complete structure disruption (\#III in Table 2): fEPS from DGCC7710 and ST143 were no longer detectable, and $\mathrm{M}_{\mathrm{M}}$ of dextran was reduced to $4 \times 10^{4} \mathrm{Da}$. The same effects were observed when the samples were neutralized after heating (\#IV). As the samples need to be dialyzed prior to GPC, it remains unknown whether fEPS were hydrolyzed completely to monosaccharides. To avoid structure disruption, neutralization after TCA treatment prior to heating (omitting simultaneous impact of acid and heat) seems to be appropriate $(\# \mathrm{~V}): \mathrm{M}_{\mathrm{M}}$ did not differ significantly from untreated samples for ST143 fEPS and dextran, and $\mathrm{M}_{\mathrm{M}}$ of DGCC7710 fEPS was only slightly lower $\left(2.49 \times 10^{6} \mathrm{Da}\right)$ than that of the untreated sample. Neutralization had the same effect when the order of thermal (first) and acid (second) treatments was changed (\#VI, \#VII).

\subsection{Effects of Enzymatic Treatment on Molecular Mass}

The use of pronase E (optimal pH: 7.5) for hydrolysis of protein impurities did not affect $\mathrm{M}_{\mathrm{M}}$ of all EPS and is therefore suitable for protein removal. Pepsin, however, reduced $\mathrm{M}_{\mathrm{M}}$ significantly (DGCC7710 fEPS: $0.67 \times 10^{6} \mathrm{Da}$; ST143 fEPS: $2.47 \times 10^{6} \mathrm{Da}$ ), as the optimal $\mathrm{pH}$ for pepsin is 2.0. Again, dextran was not affected.

\subsection{Effects of Ultrasonication on Molecular Mass and Viscosity}

Sonication for $60 \mathrm{~min}$ at room temperature in an ultrasonic water bath did not cause any significant decrease of $\mathrm{M}_{\mathrm{M}}$ for all EPS and can therefore be regarded as a useful tool to improve EPS solubility without molecular damage. However, when ultrasonication was performed at $80^{\circ} \mathrm{C}$ for $60 \mathrm{~min}$, a decrease of $\mathrm{M}_{\mathrm{M}}$ to $1.28 \times 10^{6} \mathrm{Da}$ (DGCC7710 fEPS) and to $1.64 \times 10^{6} \mathrm{Da}$ (ST143 fEPS) was observed. $\mathrm{M}_{\mathrm{M}}$ of dextran was not affected.

Sonication with the disintegrator at a power density of $114 \mathrm{~W} / \mathrm{cm}^{2}$ led to a pronounced decrease in molecular mass (Figure 2). After $20 \mathrm{~s}$ ultrasonication, $\mathrm{M}_{\mathrm{M}}$ was already 
reduced to $0.50 \times 10^{6} \mathrm{Da}$ (DGCC7710 fEPS), $0.80 \times 10^{6} \mathrm{Da}(\mathrm{ST} 143 \mathrm{fEPS}), 0.57 \times 10^{6} \mathrm{Da}$ (DGCC7919 fEPS) and $0.20 \times 10^{6} \mathrm{Da}$ (dextran). With ongoing sonication, the $\mathrm{M}_{\mathrm{M}}$ decrease was attenuated, and $\mathrm{M}_{\mathrm{M}}$ approached a limiting molecular mass $\mathrm{M}_{\mathrm{M}, \infty}$. DGCC7710 fEPS and dextran reached $\mathrm{M}_{\mathrm{M}, \infty}$ after $30 \mathrm{~min}\left(5.12 \times 10^{4} \mathrm{Da}\right.$ and $4.82 \times 10^{4} \mathrm{Da}$, respectively), i.e., no significant differences to ultrasonication for $180 \mathrm{~min}$ were observed. For ST143 fEPS and DGCC7919 fEPS, $\mathrm{M}_{\mathrm{M}, \infty}$ was reached after $60 \mathrm{~min}$ and was $8.59 \times 10^{4} \mathrm{Da}$ and $3.50 \times 10^{4} \mathrm{Da}$, respectively. The molecular mass reduction also affected the viscosity of the EPS solutions. For DGCC7710 fEPS and ST143 fEPS, 5 min ultrasonication resulted in a decrease of $\eta$ from 1.70 to $1.07 \mathrm{mPa} \cdot \mathrm{s}$ or from 1.63 to $1.07 \mathrm{mPa} \cdot \mathrm{s}$, respectively (Figure 2). With further ultrasonication, the viscosity enhancing effects of EPS diminished, and $\eta$ approached $1.0 \mathrm{mPa} \cdot \mathrm{s}$, the viscosity of water. This effect was also observed for DGCC7919 fEPS, but less pronounced (reduction from 1.19 to $1.04 \mathrm{mPa} \cdot \mathrm{s}$ after $5 \mathrm{~min}$ ) as these EPS were classified as non-ropy [38]. Dextran is a homo polysaccharide with a lower molecular mass. This resulted in a low viscosity $(\eta=1.04 \mathrm{mPa} \cdot \mathrm{s})$ which was not affected significantly by ultrasonication.

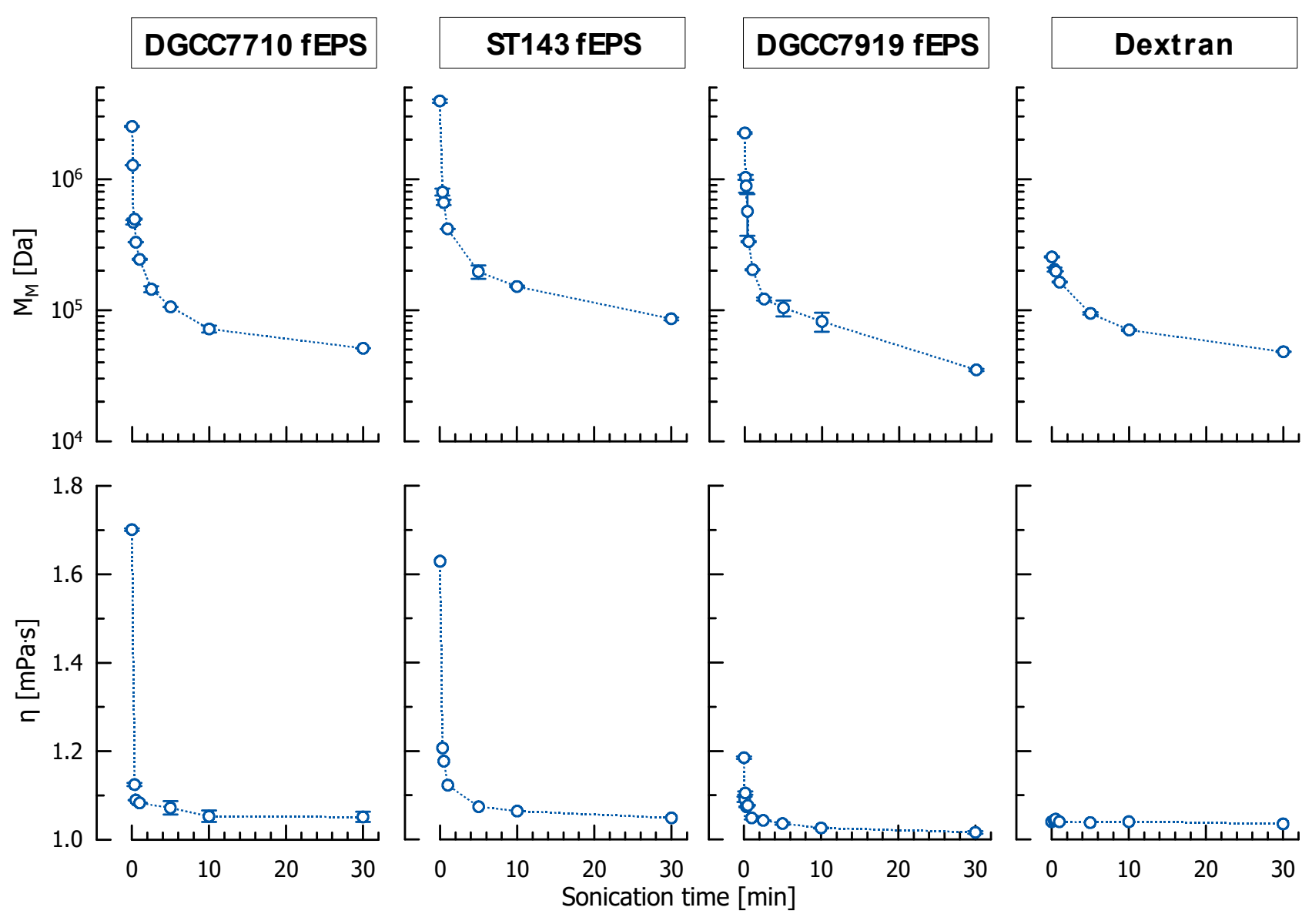

Figure 2. Weight average molecular mass $\mathrm{M}_{\mathrm{M}}$ of EPS and dynamic viscosity $\eta$ of $1.0 \mathrm{~g} / \mathrm{L}$ EPS solutions after sonication with an ultrasonic disintegrator (power density: $114 \mathrm{~W} / \mathrm{cm}^{2}$ ).

The pronounced decrease in $\mathrm{M}_{\mathrm{M}}$ by ultrasonication was already observed for other sonicated polysaccharides [35] and also for EPS treated mechanically using other systems (e.g., microfluidizer, cell disruption system) [37]. The rapid growth and collapse of cavitation bubbles, accompanied by the formation of microturbulences, is believed to be responsible for the breakage of glycosidic bonds [32]. As this occurs mainly in the center of gravity of the molecule, no monomers were formed during ultrasonication [43], as was also observed in our study. An energy density similar to our current study was applied to other polysaccharides, e.g., konjak glucomannan $\left(24-50 \mathrm{~W} / \mathrm{cm}^{2}\right)$ [26], chitosan $\left(31-62 \mathrm{~W} / \mathrm{cm}^{2}\right)$ [36] or 
polysaccharide-protein complexes from a medical fungus $\left(10-30 \mathrm{~W} / \mathrm{cm}^{2}\right)$ [39], but also higher I was introduced, e.g., for schizophyllan $\left(133-796 \mathrm{~W} / \mathrm{cm}^{2}\right)$ [22] or polysaccharides from Phellinus linteus mycelia $\left(151-453 \mathrm{~W} / \mathrm{cm}^{2}\right)$ [44]. The resulting molecular mass distributions are, however, difficult to compare due to different polysaccharide structure, concentration and temperature during ultrasonication and the initial $\mathrm{M}_{\mathrm{M}}$.

Recently, we demonstrated a linear dependency of $\eta$ on $M_{M}$ for DGCC7710 fEPS that were treated with different mechanical shearing systems (microfluidizer, cell disruption system) [37]. The regression function $\left(\eta=2.22 \times 10^{-7} \mathrm{mPa} \cdot \mathrm{s} / \mathrm{Da} \times \mathrm{M}_{\mathrm{M}}+1.03 \mathrm{mPa} \cdot \mathrm{s}\right)$ was confirmed by the ultrasonication data in this current study $\left(\mathrm{r}^{2}=0.99\right)$.

DGCC7710 fEPS were also sonicated at amplitudes $<100 \%$ to generate lower power inputs and thus EPS that are less affected by ultrasonication. An exponential decrease of $\mathrm{M}_{\mathrm{M}}$ was observed for all investigated power densities (Figure 3). Generally, a higher I caused a more pronounced decrease of $\mathrm{M}_{\mathrm{M}}$ and a lower $\mathrm{M}_{\mathrm{M} \infty}$. After $5 \mathrm{~min}, \mathrm{M}_{\mathrm{M}}$ was reduced to $1.05 \times 10^{5} \mathrm{Da}\left(114 \mathrm{~W} / \mathrm{cm}^{2}\right), 1.40 \times 10^{5} \mathrm{Da}\left(55 \mathrm{~W} / \mathrm{cm}^{2}\right), 2.04 \times 10^{5} \mathrm{Da}\left(33 \mathrm{~W} / \mathrm{cm}^{2}\right)$ or $7.92 \times 10^{5} \mathrm{Da}\left(10 \mathrm{~W} / \mathrm{cm}^{2}\right)$.

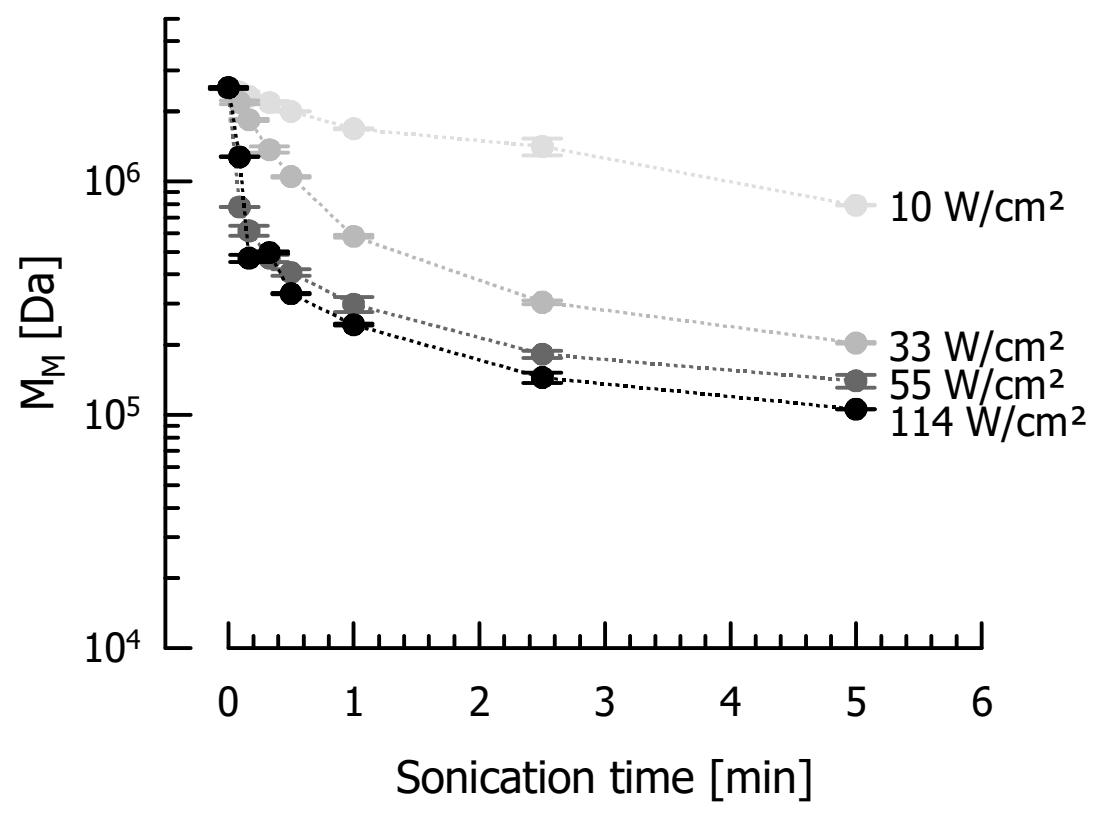

Figure 3. Weight average molecular mass $\mathrm{M}_{\mathrm{M}}$ [Da] of DGCC7710 fEPS after sonication of aqueous solutions $(1.0 \mathrm{~g} / \mathrm{L})$ with an ultrasonic disintegrator at different power densities.

The entire functions of the cumulative molecular mass distribution of untreated and ultrasonicated EPS are shown in Figure 4. As it is the case for all biological macromolecules, untreated EPS show a relatively flat distribution (left function in each chart) and therefore a broad polydispersity that can be expressed by $Đ$. With increasing ultrasonication time up to $30 \mathrm{~min}$, the slope of the functions increased, and polydispersity decreased from $Đ=2.06$ to $Đ=1.22$ (DGCC7710 fEPS), from $Đ=2.20$ to $Đ=1.26$ (ST143 fEPS), from $Đ=2.12$ to $Ð=1.55$ (DGCC7919 fEPS) and from $Đ=2.57$ to $Đ=1.58$ (dextran). This also corresponds to previous results obtained by other treatments [37]. Because $Đ$ is defined as the quotient of $M_{M} / M_{N}$ and $M_{M}$ represents larger molecules and $M_{N}$ smaller ones in a distribution curve, a decreasing $Đ$ indicates a faster decrease of $M_{M}$ than $M_{N}$, and consequently that larger molecules are more vulnerable to sonication-induced degradation than smaller ones. 

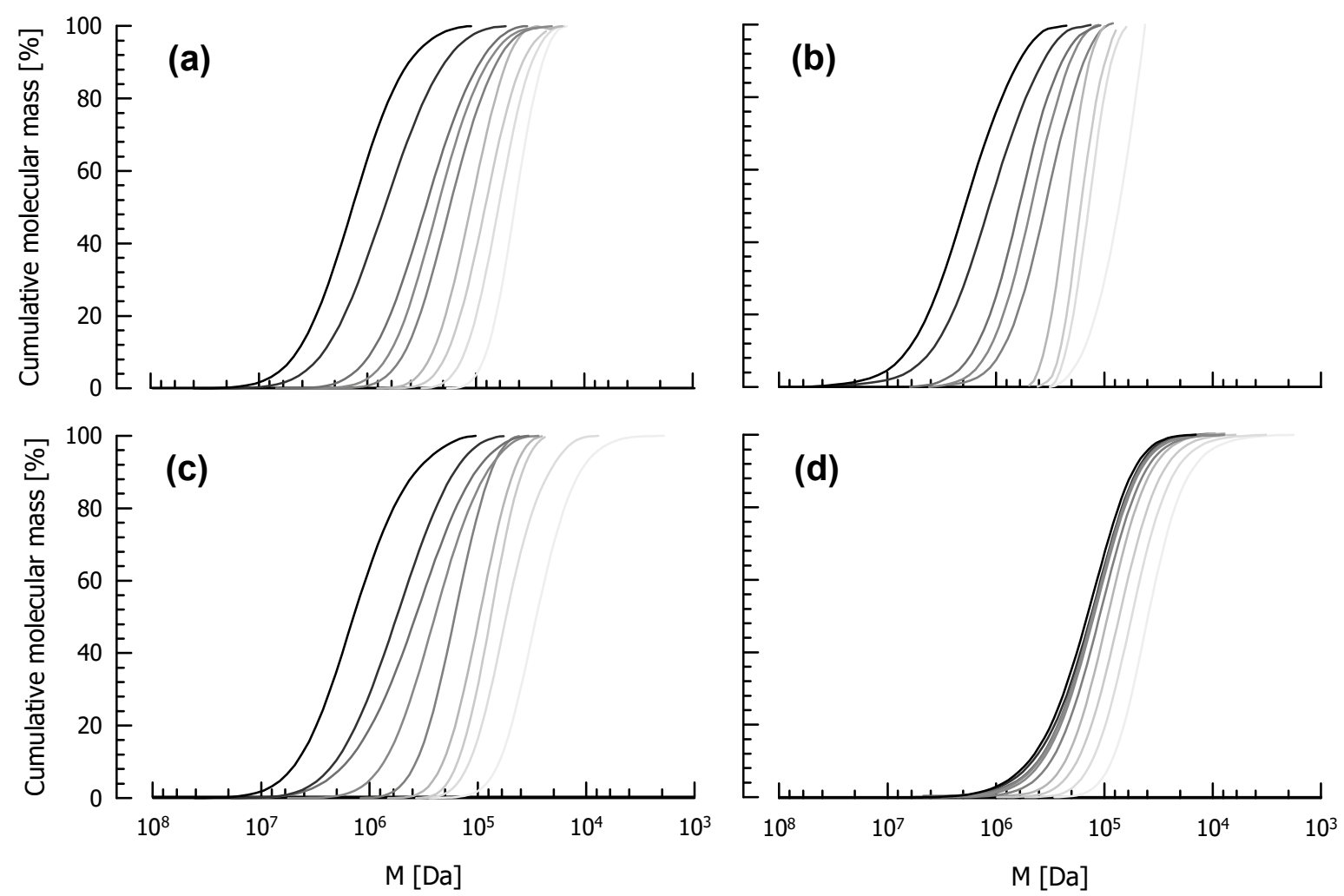

Figure 4. Cumulative molecular mass distributions of DGCC7710 fEPS (a), ST143 fEPS (b), DGCC7919 fEPS (c) and dextran (d). EPS solutions $\left(1.0 \mathrm{~g} / \mathrm{L}\right.$ ) were treated with an ultrasonic disintegrator (power density: $\left.114 \mathrm{~W} / \mathrm{cm}^{2}\right)$ for $0 \mathrm{~s}, 5 \mathrm{~s}, 10 \mathrm{~s}, 20 \mathrm{~s}$, $30 \mathrm{~s}, 2.5 \mathrm{~min}, 5 \mathrm{~min}, 10 \mathrm{~min}, 30 \mathrm{~min}$ (dark to light grey). M: molecular mass.

\subsection{Exopolysaccharide Degradation Kinetics}

Different kinetic models were used to describe EPS degradation as a function of experimental parameters. First order degradation follows Equation (5) [22,44]:

$$
\ln \mathrm{M}_{\mathrm{M}, \mathrm{t}}=\mathrm{k}^{\prime} \cdot \mathrm{t}+\ln \mathrm{M}_{\mathrm{M}, 0}
$$

The Malhotra model follows second-order kinetics [45]:

$$
\frac{1}{\mathrm{M}_{\mathrm{M}, \mathrm{t}}}=\mathrm{k}^{\prime \prime} \cdot \mathrm{t}+\frac{1}{\mathrm{M}_{\mathrm{M}, 0}}
$$

Wu et al. [36] proposed a third-order equation to follow sonication-induced degradation of chitosan:

$$
\frac{1}{\mathrm{M}_{\mathrm{M}, \mathrm{t}}^{2}}=\mathrm{k}^{\prime \prime \prime} \cdot \mathrm{t}+\frac{1}{\mathrm{M}_{\mathrm{M}, 0}^{2}}
$$

$\mathrm{M}_{\mathrm{M}, 0}[\mathrm{Da}]$ and $\mathrm{M}_{\mathrm{M}, \mathrm{t}}[\mathrm{Da}]$ refer to the weight average molecular mass of untreated EPS and EPS after a certain ultrasonication time $t$ [min], respectively, and $\mathrm{k}^{\prime}[1 / \mathrm{min}]$, $\mathrm{k}^{\prime \prime}[1 /(\mathrm{Da} \cdot \mathrm{min})]$ and $\mathrm{k}^{\prime \prime \prime}\left[1 /\left(\mathrm{Da}^{2} \cdot \mathrm{min}\right)\right]$ to the rate constants for first-, second- and thirdorder degradation, respectively, under defined ultrasonication conditions (sonotrode geometry, amplitude, frequency, temperature, polymer, volume and concentration of sample solution). The effect of ultrasonication on a polymer is thus reflected by $\mathrm{k}$ : a lower $\mathrm{k}$ refers to increased resistance and therefore a lower decrease of $\mathrm{M}_{\mathrm{M}}$.

The weight average molecular mass of ultrasonicated EPS was fitted into the outlined functions (Table 3). None of the EPS followed first-order degradation kinetics. At the highest power density of the disintegrator $\left(114 \mathrm{~W} / \mathrm{cm}^{2}\right)$, DGCC7710 fEPS, ST143 fEPS and DGCC7919 followed third-order kinetics, as indicated by the highest $\mathrm{r}^{2}$. This was 
proposed by Wu et al. [36] for the degradation of chitosan. At lower power density, the rate constants decreased and were almost similar for second- and third-order (e.g., 0.99 for DGCC7710 fEPS at $\left.\mathrm{I}=10 \mathrm{~W} / \mathrm{cm}^{2}\right)$. This is also true for dextran $\left(\mathrm{r}^{2}=0.98\right.$ for both second- and third-order at $\mathrm{I}=114 \mathrm{~W} / \mathrm{cm}^{2}$ ). Pu et al. [27] and Lorimer et al. [46] also observed that degradation of dextran with different molecular mass distribution fitted into the second-order Malhotra model. However, EPS degradation is not a direct function of power density. Therefore, we assume that the degradation rate reaches a certain limiting value with increasing I.

Table 3. Rate constants $\mathrm{k}^{\prime}, \mathrm{k}^{\prime \prime}$ and $\mathrm{k}^{\prime \prime \prime}$ of different degradation models, applied to ultrasonicated EPS at different power density I $\left[\mathrm{W} / \mathrm{cm}^{2}\right]$.

\begin{tabular}{|c|c|c|c|c|c|c|c|}
\hline \multirow{2}{*}{ EPS } & \multirow{2}{*}{$\mathrm{I}\left[\mathrm{W} / \mathrm{cm}^{2}\right]$} & \multicolumn{2}{|c|}{$\begin{array}{c}\text { 1st Order } \\
\text { Degradation }\end{array}$} & \multicolumn{2}{|c|}{$\begin{array}{c}\text { 2nd Order } \\
\text { Degradation }\end{array}$} & \multicolumn{2}{|c|}{$\begin{array}{c}\text { 3rd Order } \\
\text { Degradation }\end{array}$} \\
\hline & & $\begin{array}{c}\mathbf{k}^{\prime} \\
{[1 / \mathrm{min}]}\end{array}$ & $\mathbf{r}^{2}$ & $\begin{array}{c}\mathbf{k}^{\prime \prime} \\
{[1 /(\mathrm{Da} \cdot \mathrm{min})]}\end{array}$ & $\mathbf{r}^{2}$ & $\begin{array}{c}\mathbf{k}^{\prime \prime \prime} \\
{\left[1 /\left(\mathrm{Da}^{2} \cdot \min \right)\right]}\end{array}$ & $\mathbf{r}^{2}$ \\
\hline \multirow[t]{4}{*}{$\begin{array}{l}\text { DGCC7710 } \\
\text { fEPS }\end{array}$} & 114 & $-4.76 \times 10^{-1}$ & 0.59 & $1.74 \times 10^{-6}$ & 0.93 & $1.80 \times 10^{-11}$ & 0.99 \\
\hline & 55 & $-4.13 \times 10^{-1}$ & 0.58 & $1.34 \times 10^{-6}$ & 0.92 & $1.19 \times 10^{-11}$ & 0.99 \\
\hline & 33 & $-4.96 \times 10^{-1}$ & 0.83 & $9.36 \times 10^{-7}$ & 0.98 & $4.59 \times 10^{-12}$ & 0.98 \\
\hline & 10 & $-4.03 \times 10^{-1}$ & 0.94 & $1.86 \times 10^{-7}$ & 0.99 & $1.66 \times 10^{-13}$ & 0.99 \\
\hline ST143 fEPS & 114 & $-3.75 \times 10^{-1}$ & 0.64 & $8.51 \times 10^{-7}$ & 0.94 & $5.15 \times 10^{-12}$ & 0.99 \\
\hline $\begin{array}{c}\text { DGCC7919 } \\
\text { fEPS }\end{array}$ & 114 & $-5.04 \times 10^{-1}$ & 0.64 & $1.88 \times 10^{-6}$ & 0.88 & $2.02 \times 10^{-11}$ & 0.96 \\
\hline Dextran & 114 & $-1.76 \times 10^{-1}$ & 0.93 & $1.26 \times 10^{-6}$ & 0.98 & $3.60 \times 10^{-12}$ & 0.98 \\
\hline
\end{tabular}

Wu et al. [36] showed that $\mathrm{k}$ is independent from $\mathrm{M}_{\mathrm{M}, 0}$. Therefore, EPS with different initial molecular mass can be compared regarding their shearing resistance by means of the rate constant $\mathrm{k}^{\prime \prime \prime}$ at $\mathrm{I}=114 \mathrm{~W} / \mathrm{cm}^{2}$. DGCC7710 fEPS were most vulnerable to ultrasonication, followed by DGCC7919 and dextran. ST143 fEPS showed the highest resistance against sonication as its $\mathrm{k}^{\prime \prime \prime}$ was lowest. With decreasing ultrasound density, $\mathrm{k}^{\prime \prime \prime}$ decreased, as indicated by the data for DGCC7710 fEPS. It still remains unclear whether the different behavior of dextran is due to the structural differences compared to EPS from S. thermophilus.

Overall, our experiments showed that the EPS investigated in this study reacted differently to the thermal, chemical, enzymatic and ultrasound treatment. A higher sensitivity to chemical and thermal stress was in accordance with the observed sensitivity to mechanical energy input created by ultrasonication and was in the order DGCC7710 fEPS > DGCC7919 fEPS > dextran > ST143 fEPS. The EPS differ strongly in their chemical structures (Figure 5). Other than a different monosaccharide composition (glucose, galactose, rhamnose), these were differently linked. In the EPS backbone, 1,2- and 1,3-glycosidic linkages (as found solely in DGCC7710 fEPS) lead to more flexible molecules than 1,4-linkages (as found solely in ST143 fEPS) $[5,47,48]$. Enhanced flexibility is supposed to be associated with reduced sensitivity to mechanical energy input. Furthermore, $\beta$-linked monomers (as found mainly in ST143 fEPS) showed reduced flexibility compared to $\alpha$-linkages (50\% in DGCC7710 fEPS and DGCC7919 fEPS, 20\% in ST143 fEPS) [10]. Tuinier et al. [9] observed that the presence of side chains impeded the entanglement of polysaccharide molecules and reduced the flexibility of the EPS backbone. In our study, the EPS with the longest side chain (ST143 fEPS) was least sensitive to external stress. Dextran, composed of a flexible $\alpha-1,6$-linked glucopyranose chain with a low amount of 1,3,6-linkages [37], and DGCC7710 fEPS have monomeric side chains, but were differently affected by thermal, chemical and ultrasound treatments. As specific structural features interact with each other, a conclusive evaluation of the stress sensitivity induced by specific EPS structural details still remains challenging. To link distinct structural features to the sensitivity against external stresses, it is necessary to compare two EPS that differ in only one parameter, e.g., the presence of a monomeric 
side chain. This could be realized by enzymatic removal of those side chains of an EPS from lactic acid bacteria.

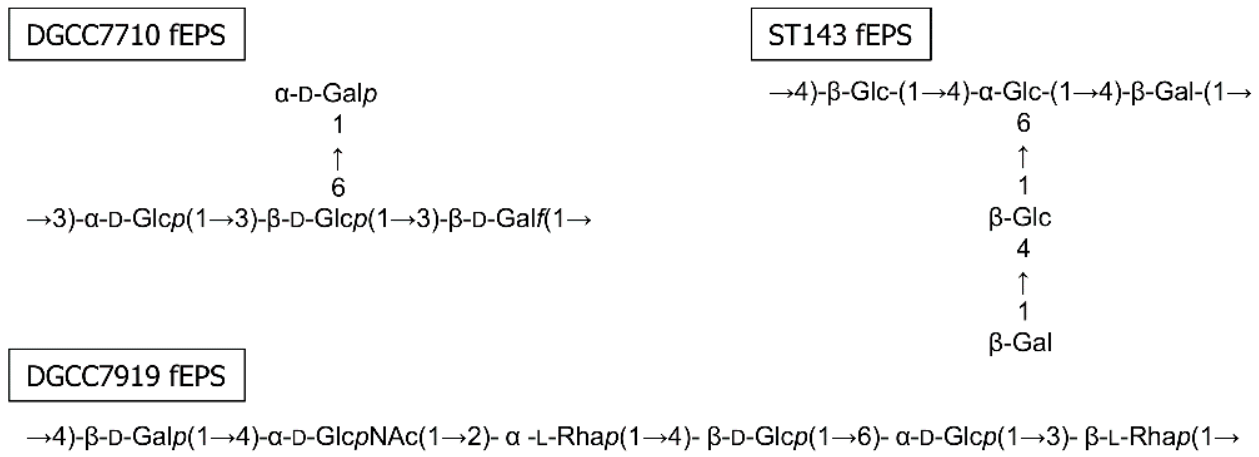

Figure 5. EPS structures of DGCC7710 fEPS [37], ST143 fEPS [49] and DGCC7919 fEPS [38].

\subsection{Investigation of Chain Scission Models}

After linearization of Equations (1) and (2), the number average molecular mass of the EPS can be used to determine the localization of chain scission during ultrasonication. $\mathrm{M}_{\mathrm{N}, \infty}$ was determined experimentally by sonication with an ultrasonic disintegrator for three hours as proposed earlier by Wu et al. [36]. Data of all investigated EPS fitted closely to the random scission model $\left(\mathrm{r}^{2}>0.98\right)$ but not to the midpoint scission model $\left(\mathrm{r}^{2}<0.89\right)$, suggesting an unsystematic breakdown of glycosidic bonds with evenly distributed scission points over the entire EPS molecule during ultrasonication (Figure 6). HPLC analyses supported these findings by revealing that no mono- and disaccharides were released during ultrasonication.

The linear dependency of $\eta$ on $\mathrm{M}_{\mathrm{M}}$, evident for ultrasonication and shearing with a microfluidizer or a cell disruption system, indicates the same degradation mechanism of molecule breakdown for the different treatments. This is also consistent with findings from NMR experiments where we observed that microfluidization does not alter EPS structure [37]. Studies point to unaltered structures after ultrasonication, however, in some studies, the FT-IR measurements might not have been sensitive enough to detect minor changes of EPS structure $[28,30,44,50,51]$. The random chain scission was proved for the majority of polysaccharides, e.g., chitosan [36], konjak glucomannan [26,33], pectin [51], (1-3)(1-6)- $\alpha$-D-glucans from Leuconostoc citreum [21] or polysaccharides from Sargassum pallidum [50]. For some polysaccharides, such as carboxylic curdlan [28] and six different dextrans from L. mesenteroides [27], however, midpoint chain scission was observed, which is in contrast to our study, where dextran also fitted the random chain scission model. This may be due to the fact that other authors used the viscosity-average molecular mass (instead of number-average) or did not state which molecular mass was used for the calculations. Furthermore, the degree of branching may also affect the degradation mechanism of dextran. 


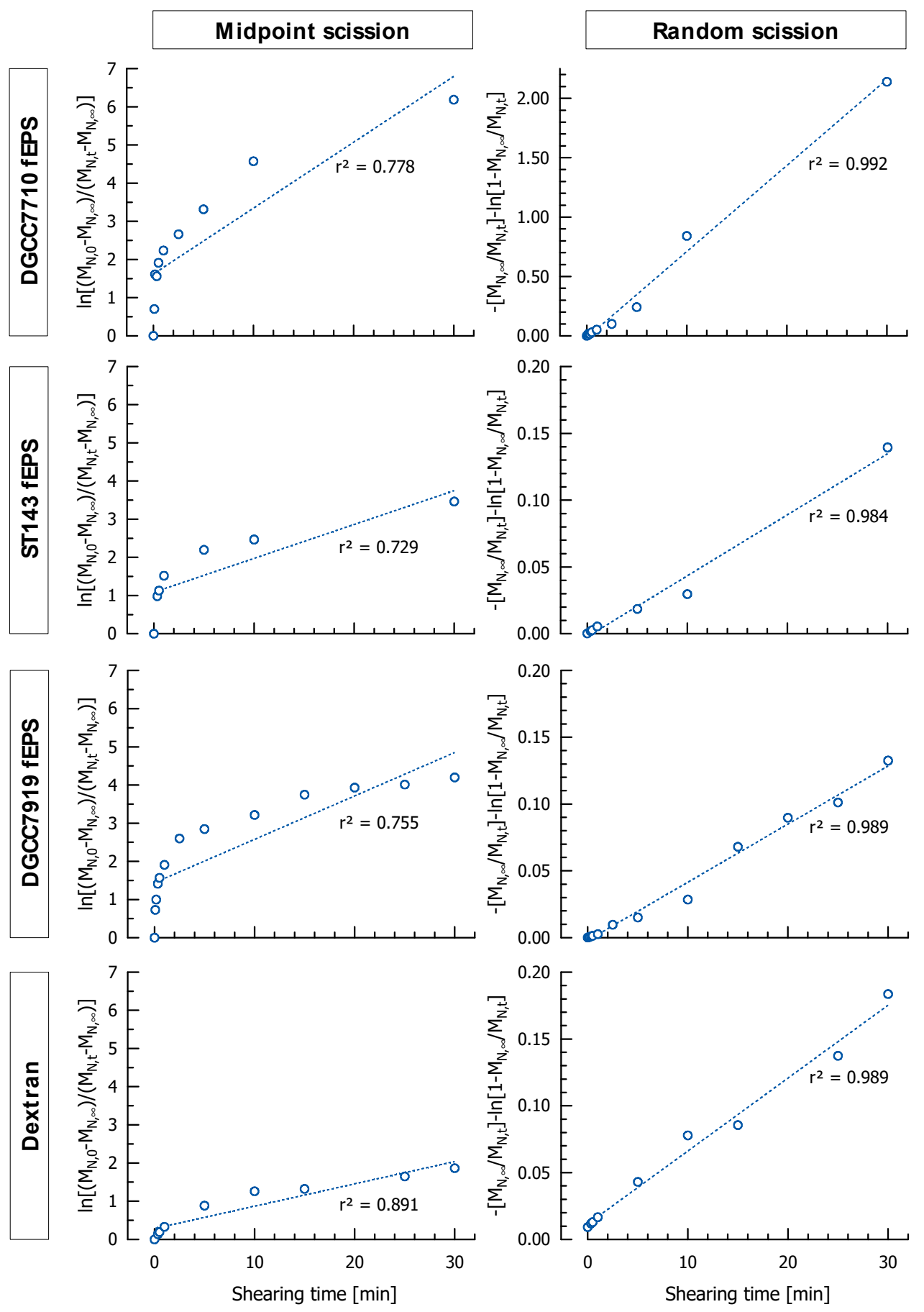

Figure 6. Linearization plot of the midpoint scission model (Equation (2)) and the random scission model (Equation (1)) for ultrasonicated EPS (power density: $114 \mathrm{~W} / \mathrm{cm}^{2}$ ).

\section{Conclusions}

The investigated EPS were largely affected by acid and ultrasonication treatment. As the $\mathrm{M}_{\mathrm{M}}$ decrease was only $8 \%$ at maximum after $10 \mathrm{~min}$ at $90{ }^{\circ} \mathrm{C}$, we suggest this step for cEPS detachment or resolvatization of isolated EPS. Furthermore, applying combinations of heat with other treatments simultaneously should be avoided, as this enhanced the degrading effect of ultrasound or $\mathrm{pH}$ (used for acid protein precipitation, leading to acid EPS hydrolysis). EPS degradation can be further reduced by replacing acid precipitation by enzymatic hydrolysis for protein removal. The ultrasonic disintegrator was shown to be inappropriate for EPS isolation because it rapidly reduced $\mathrm{M}_{\mathrm{M}}$ of all the 
exopolysaccharides. On the other hand, it may be useful for a targeted modification of EPS, especially at lower power density, and for the investigation of degradation mechanisms and kinetics. We observed that all EPS chains were broken randomly (Schmid model) following third- (DGCC7710 fEPS, DGCC7919 fEPS, ST143 fEPS) or second-order kinetics (dextran). The sensitivity to ultrasonication at $114 \mathrm{~W} / \mathrm{cm}^{2}$ was highest for DGCC7710 fEPS $\left(\mathrm{k}^{\prime \prime \prime}=1.80 \times 10^{-11}\right)$, followed by DGCC7919 fEPS $\left(2.02 \times 10^{-11}\right)$, dextran $\left(3.60 \times 10^{-12}\right)$ and ST143 fEPS $\left(5.15 \times 10^{-12}\right)$. The data confirmed a linear relationship between $\mathrm{M}_{\mathrm{M}}$ and $\eta$, as recently published for other shearing systems. Ultrasonication showed to be a promising tool to easily adjust $\eta$ and $\mathrm{M}_{\mathrm{M}}$ of EPS by selecting the appropriate sonication parameters (amplitude, time) after empirical calibration. This allows to obtain EPS isolates with desired functionality for their use in nonfermented foods and beverages.

Author Contributions: C.N. designed the experiments, performed the experiments and analyzed the data; D.J. co-supervised the work; C.N., D.J. and H.R. wrote the manuscript. All authors have read and agreed to the published version of the manuscript.

Funding: This research was funded by Deutsche Forschungsgemeinschaft (Bonn, Germany), grant number JA2033/1-2.

Data Availability Statement: The datasets generated for this study are available on request to the corresponding author.

Acknowledgments: We wish to thank Danisco Deutschland GmbH (Niebüll, Germany) and Christian Hansen A/S (Hørsholm, Denmark) for providing the strains. The assistance of Christiane Berger in obtaining the data is gratefully acknowledged.

Conflicts of Interest: The authors declare no conflict of interests.

\section{References}

1. Mende, S.; Rohm, H.; Jaros, D. Influence of Exopolysaccharides on the Structure, Texture, Stability and Sensory Properties of Yoghurt and Related Products. Int. Dairy J. 2016, 52, 57-71. [CrossRef]

2. Folkenberg, D.M.; Dejmek, P.; Skriver, A.; Ipsen, R. Relation between Sensory Texture Properties and Exopolysaccharide Distribution in Set and in Stirred Yoghurts Produced with Different Starter Cultures. J. Texture Stud. 2005, 36, 174-189. [CrossRef]

3. Lynch, K.M.; Zannini, E.; Coffey, A.; Arendt, E.K. Lactic Acid Bacteria Exopolysaccharides in Foods and Beverages: Isolation, Properties, Characterization, and Health Benefits. Annu. Rev. Food Sci. Technol. 2018, 9, 155-176. [CrossRef]

4. De Vuyst, L.; Degeest, B. Heteropolysaccharides from Lactic Acid Bacteria. FEMS Microbiol. Rev. 1999, 23, 153-177. [CrossRef]

5. Zhou, Y.; Cui, Y.; Qu, X. Exopolysaccharides of Lactic Acid Bacteria: Structure, Bioactivity and Associations: A Review. Carbohydr. Polym. 2019, 207, 317-332. [CrossRef]

6. Zannini, E.; Waters, D.M.; Coffey, A.; Arendt, E.K. Production, Properties, and Industrial Food Application of Lactic Acid Bacteria-Derived Exopolysaccharides. Appl. Microbiol. Biotechnol. 2016, 100, 1121-1135. [CrossRef] [PubMed]

7. Kavitake, D.; Devi, P.B.; Shetty, P.H. Overview of Exopolysaccharides Produced by Weissella Genus-A Review. Int. J. Biol. Macromol. 2020, 164, 2964-2973. [CrossRef]

8. Xu, Y.; Cui, Y.; Yue, F.; Liu, L.; Shan, Y.; Liu, B.; Zhou, Y.; Lü, X. Exopolysaccharides Produced by Lactic Acid Bacteria and Bifidobacteria: Structures, Physiochemical Functions and Applications in the Food Industry. Food Hydrocoll. 2019, 94, 475-499. [CrossRef]

9. Tuinier, R.; Van Calsteren, M.-R.; Looijesteijn, P.J.; Schols, H.A.; Voragen, A.G.J.; Zoon, P. Effects of Structural Modifications on Some Physical Characteristics of Exopolysaccharides from Lactococcus lactis. Biopolymers 2001, 59, 160-166. [CrossRef]

10. Laws, A.P.; Marshall, V.M. The Relevance of Exopolysaccharides to the Rheological Properties in Milk Fermented with Ropy Strains of Lactic Acid Bacteria. Int. Dairy J. 2001, 11, 709-721. [CrossRef]

11. Rimada, P.S.; Abraham, A.G. Comparative Study of Different Methodologies to Determine the Exopolysaccharide Produced by Kefir Grains in Milk and Whey. Lait 2003, 83, 79-87. [CrossRef]

12. Mende, S.; Mentner, C.; Thomas, S.; Rohm, H.; Jaros, D. Exopolysaccharide Production by Three Different Strains of Streptococcus Thermophilus and Its Effect on Physical Properties of Acidified Milk. Eng. Life Sci. 2012, 12, 466-474. [CrossRef]

13. Nguyen, A.T.-B.; Nigen, M.; Jimenez, L.; Ait-Abderrahim, H.; Marchesseau, S.; Picart-Palmade, L. Performances of Different Protocols for Exocellular Polysaccharides Extraction from Milk Acid Gels: Application to Yogurt. Food Chem. 2018, 239, 742-750. [CrossRef]

14. Zhang, N.; Chen, H.; Ma, L.; Zhang, Y. Physical Modifications of Polysaccharide from Inonotus Obliquus and the Antioxidant Properties. Int. J. Biol. Macromol. 2013, 54, 209-215. [CrossRef] 
15. Ruas-Madiedo, P.; Gueimonde, M.; Margolles, A.; de los Losreyes-Gavilán, C.G.; Salminen, S. Exopolysaccharides Produced by Probiotic Strains Modify the Adhesion of Probiotics and Enteropathogens to Human Intestinal Mucus. J. Food Prot. 2006, 69, 2011-2015. [CrossRef] [PubMed]

16. Notararigo, S.; Nácher-Vázquez, M.; Ibarburu, I.; Werning, M.L.; de Palencia, P.F.; Dueñas, M.T.; Aznar, R.; López, P.; Prieto, A. Comparative Analysis of Production and Purification of Homo- and Hetero-Polysaccharides Produced by Lactic Acid Bacteria. Carbohydr. Polym. 2013, 93, 57-64. [CrossRef]

17. Ruas-Madiedo, P.; De Los Reyes-Gavilán, C.G. Invited Review: Methods for the Screening, Isolation, and Characterization of Exopolysaccharides Produced by Lactic Acid Bacteria. J. Dairy Sci. 2005, 88, 843-856. [CrossRef]

18. Leroy, F.; De Vuyst, L. Advances in Production and Simplified Methods for Recovery and Quantification of Exopolysaccharides for Applications in Food and Health. J. Dairy Sci. 2016, 99, 3229-3238. [CrossRef]

19. Nachtigall, C.; Vogel, C.; Rohm, H.; Jaros, D. How Capsular Exopolysaccharides Affect Cell Surface Properties of Lactic Acid Bacteria. Microorganisms 2020, 8, 1904. [CrossRef] [PubMed]

20. Nachtigall, C.; Surber, G.; Bulla, J.; Rohm, H.; Jaros, D. Pilot Scale Isolation of Exopolysaccharides from Streptococcus Thermophilus DGCC7710: Impact of Methodical Details on Macromolecular Properties and Technofunctionality. Eng. Life Sci. $2020,73$. [CrossRef]

21. Huang, C.; Miao, M.; Jiang, B.; Cui, S.W.; Jia, X.; Zhang, T. Polysaccharides Modification through Green Technology: Role of Ultrasonication towards Improving Physicochemical Properties of (1-3)(1-6)- $\alpha$-d-Glucans. Food Hydrocoll. 2015, 50, 166-173. [CrossRef]

22. Zhong, K.; Zhang, Q.; Tong, L.; Liu, L.; Zhou, X.; Zhou, S. Molecular Weight Degradation and Rheological Properties of Schizophyllan under Ultrasonic Treatment. Ultrason. Sonochem. 2015, 23, 75-80. [CrossRef]

23. Freitas, F.; Alves, V.D.; Reis, M.A.M. Advances in Bacterial Exopolysaccharides: From Production to Biotechnological Applications. Trends Biotechnol. 2011, 29, 388-398. [CrossRef]

24. Wang, Z.-M.; Cheung, Y.-C.; Leung, P.-H.; Wu, J.-Y. Ultrasonic Treatment for Improved Solution Properties of a High-Molecular Weight Exopolysaccharide Produced by a Medicinal Fungus. Bioresour. Technol. 2010, 101, 5517-5522. [CrossRef] [PubMed]

25. Ogutu, F.O. Ultrasonic Modification of Selected Polysaccharides-Review. J. Food Process. Technol. 2015, 6, 5. [CrossRef]

26. Li, J.; Li, B.; Geng, P.; Song, A.-X.; Wu, J.-Y. Ultrasonic Degradation Kinetics and Rheological Profiles of a Food Polysaccharide (Konjac Glucomannan) in Water. Food Hydrocoll. 2017, 70, 14-19. [CrossRef]

27. Pu, Y.; Zou, Q.; Hou, D.; Zhang, Y.; Chen, S. Molecular Weight Kinetics and Chain Scission Models for Dextran Polymers during Ultrasonic Degradation. Carbohydr. Polym. 2017, 156, 71-76. [CrossRef] [PubMed]

28. Yan, J.-K.; Pei, J.-J.; Ma, H.-L.; Wang, Z.-B. Effects of Ultrasound on Molecular Properties, Structure, Chain Conformation and Degradation Kinetics of Carboxylic Curdlan. Carbohydr. Polym. 2015, 121, 64-70. [CrossRef]

29. Petit, A.-C.; Noiret, N.; Guezennec, J.; Gondrexon, N.; Colliec-Jouault, S. Ultrasonic Depolymerization of an Exopolysaccharide Produced by a Bacterium Isolated from a Deep-Sea Hydrothermal Vent Polychaete Annelid. Ultrason. Sonochem. 2007, 14, 107-112 [CrossRef]

30. Du, B.; Zeng, H.; Yang, Y.; Bian, Z.; Xu, B. Anti-Inflammatory Activity of Polysaccharide from Schizophyllum Commune as Affected by Ultrasonication. Int. J. Biol. Macromol. 2016, 91, 100-105. [CrossRef] [PubMed]

31. Yuan, Q.; He, Y.; Xiang, P.-Y.; Huang, Y.-J.; Cao, Z.-W.; Shen, S.-W.; Zhao, L.; Zhang, Q.; Qin, W.; Wu, D.-T. Influences of Different Drying Methods on the Structural Characteristics and Multiple Bioactivities of Polysaccharides from Okra (Abelmoschus Esculentus). Int. J. Biol. Macromol. 2020, 147, 1053-1063. [CrossRef]

32. Basedow, A.M.; Ebert, K.H. Ultrasonic degradation of polymers in solution. In Physical Chemistry; Springer: Berlin/Heidelberg, Germany, 1977; Volume 22, pp. 83-148. ISBN 978-3-540-07942-2.

33. Yin, J.-Y.; Ma, L.-Y.; Siu, K.-C.; Wu, J.-Y. Effects of Ultrasonication on the Conformational, Microstructural, and Antioxidant Properties of Konjac Glucomannan. Appl. Sci. 2019, 9, 461. [CrossRef]

34. Schmid, G. Zur Kinetik Der Ultraschalldepolymerisation. Z. Physikal. Chem. 1940, 186, 113-128. [CrossRef]

35. Madras, G.; Kumar, S.; Chattopadhyay, S. Continuous Distribution Kinetics for Ultrasonic Degradation of Polymers. Polym. Degrad. Stab. 2000, 69, 73-78. [CrossRef]

36. Wu, T.; Zivanovic, S.; Hayes, D.G.; Weiss, J. Efficient Reduction of Chitosan Molecular Weight by High-Intensity Ultrasound: Underlying Mechanism and Effect of Process Parameters. J. Agric. Food Chem. 2008, 56, 5112-5119. [CrossRef] [PubMed]

37. Nachtigall, C.; Berger, C.; Kovanović, T.; Wefers, D.; Jaros, D.; Rohm, H. Shear Induced Molecular Changes of Exopolysaccharides from Lactic Acid Bacteria. Food Hydrocoll. 2019, 97, 105181. [CrossRef]

38. Nachtigall, C.; Surber, G.; Herbi, F.; Wefers, D.; Jaros, D.; Rohm, H. Production and Molecular Structure of Heteropolysaccharides from Two Lactic Acid Bacteria. Carbohydr. Polym. 2020, 236, 116019. [CrossRef] [PubMed]

39. Cheung, Y.-C.; Liu, X.-X.; Wang, W.-Q.; Wu, J.-Y. Ultrasonic Disruption of Fungal Mycelia for Efficient Recovery of PolysaccharideProtein Complexes from Viscous Fermentation Broth of a Medicinal Fungus. Ultrason. Sonochem. 2015, 22, 243-248. [CrossRef] [PubMed]

40. Liu, D.; Vorobiev, E.; Savoire, R.; Lanoisellé, J.-L. Comparative Study of Ultrasound-Assisted and Conventional Stirred Dead-End Microfiltration of Grape Pomace Extracts. Ultrason. Sonochem. 2013, 20, 708-714. [CrossRef]

41. Viñarta, S.C.; Delgado, O.D.; Figueroa, L.I.C.; Fariña, J.I. Effects of Thermal, Alkaline and Ultrasonic Treatments on Scleroglucan Stability and Flow Behavior. Carbohydr. Polym. 2013, 94, 496-504. [CrossRef] 
42. Lu, X.; Li, N.; Qiao, X.; Qiu, Z.; Liu, P. Effects of Thermal Treatment on Polysaccharide Degradation during Black Garlic Processing. LWT 2018, 95, 223-229. [CrossRef]

43. Kulicket, W.-M.; Kull, A.H.; Kull, W.; Thielking, H.; Engelhard, J.; Pannek, J.-B. Characterization of Aqueous Carboxymethylcellulose Solutions in Terms of Their Molecular Structure and Its Influence on Rheological Behaviour. Polymer 1996, 37, $2723-2731$. [CrossRef]

44. Yan, J.-K.; Wang, Y.-Y.; Ma, H.-L.; Wang, Z.-B. Ultrasonic Effects on the Degradation Kinetics, Preliminary Characterization and Antioxidant Activities of Polysaccharides from Phellinus Linteus Mycelia. Ultrason. Sonochem. 2016, 29, 251-257. [CrossRef]

45. Malhotra, S.L. Ultrasonic Solution Degradations of Poly(Alkyl Methacrylates). J. Macromol. Sci. Chem. 1986, $23,729-748$. [CrossRef]

46. Lorimer, J.P.; Mason, T.J.; Cuthbert, T.C.; Brookfield, E.A. Effect of Ultrasound on the Degradation of Aqueous Native Dextran. Ultrason. Sonochem. 1995, 2, S55-S57. [CrossRef]

47. Welman, A.D.; Maddox, I.S. Exopolysaccharides from Lactic Acid Bacteria: Perspectives and Challenges. Trends Biotechnol. 2003, 21, 269-274. [CrossRef]

48. Ruas-Madiedo, P.; Tuinier, R.; Kanning, M.; Zoon, P. Role of Exopolysaccharides Produced by Lactococcus lactis Subsp. Cremoris on the Viscosity of Fermented Milks. Int. Dairy J. 2002, 12, 689-695.

49. Pachekrepapol, U.; Lucey, J.A.; Gong, Y.; Naran, R.; Azadi, P. Corrigendum to "Characterization of the Chemical Structures and Physical Properties of Exopolysaccharides Produced by Various Streptococcus Thermophilus Strains". J. Dairy Sci. 2018, 101, 5668. [CrossRef]

50. Yuan, D.; Li, C.; Huang, Q.; Fu, X. Ultrasonic Degradation Effects on the Physicochemical, Rheological and Antioxidant Properties of Polysaccharide from Sargassum Pallidum. Carbohydr. Polym. 2020, 239, 116230. [CrossRef] [PubMed]

51. Zhang, L.; Ye, X.; Ding, T.; Sun, X.; Xu, Y.; Liu, D. Ultrasound Effects on the Degradation Kinetics, Structure and Rheological Properties of Apple Pectin. Ultrason. Sonochem. 2013, 20, 222-231. [CrossRef] 